\title{
HIGH PREVALENCE OF LOUSE FLIES ON OSPREY NESTLINGS IN A BAJA CALIFORNIA COLONY
}

\author{
RICARDO RODRÍGUEZ-ESTRELLA ${ }^{1}$ \\ Centro de Investigaciones Biológicas del Noroeste, Conservation and Environmental Planning Program, Av. \\ Instituto Politécnico Nacional 195, Col. Playa Palo de Santa Rita Sur, La Paz, BCS, 23096, México \\ and \\ University of Arizona, School of Natural Resources and the Environment, Environment and Natural Resources \\ Building 2, Tucson, AZ 85721 USA \\ LAURA B. RIVERA-RODRÍGUEZ ${ }^{2}$ \\ Centro de Investigaciones Biológicas del Noroeste, Conservation and Environmental Planning Program, Av. \\ Instituto Politécnico Nacional 195, Col. Playa Palo de Santa Rita Sur, La Paz, BCS, 23096, México

\begin{abstract}
We studied the prevalence of a louse fly (Olfersia fumipennis) in a dense breeding colony of Ospreys (Pandion haliaetus) at San Ignacio Lagoon, Baja California Sur, Mexico. We determined fly prevalence and infestation intensity of 45 nestlings (age 32-59 d). We found louse flies in $65 \%$ of the nests sampled $(n=34)$. Louse fly prevalence in nestlings $(n=45)$ was $56 \%$, the highest rate reported for any raptor species. Male and female nestlings showed similar levels of fly prevalence and infestation, possibly because the numbers of each sex in this population were similar. We found that louse flies had a spatially dispersed distribution, such that the proximity of any nest to any other within the colony did not influence the prevalence of louse flies nor the louse fly load. The productivity of nests with parasitized young $(1.3 \pm 0.5$ young/nest) was similar to that of nests with young that were not parasitized ( $1.4 \pm 0.6$ young/nest; $P>0.05)$. In terms of spatial location, the overall productivity (number of young per successful nest) of the colony was affected by louse fly prevalence. The condition of coloniality (i.e., high density of nests) likely caused high overall louse fly prevalence. A high prevalence of parasitism might be part of the cost of nesting in colonial conditions. Additional studies on the prevalence of louse flies and the health and body condition of nestlings are needed to evaluate the health of Osprey populations.
\end{abstract}

Key Words: Osprey; Pandion haliaetus; louse fly; Olfersia fumipennis; Baja California; infestation; Mexico; parasite, reproductive rate, sex ratio.

\section{ALTA PREVALENCIA DE OLFERSIA FUMIPENNIS EN POLLOS DE PANDION HALIAETUS EN UNA COLONIA DE BAJA CALIFORNIA}

Resumen.-Estudiamos la prevalencia de Olfersia fumipennis, un ectoparásito hematófago, en una colonia reproductora densa de Pandion haliaetus en la Laguna San Ignacio, Baja California Sur, México. Determinamos la prevalencia y la intensidad de infección con Olfersia fumipennis en 45 pollos (edades entre 32-59 días). Un 65\% de los nidos $(n=34)$ estaba parasitado. La prevalencia de Olfersia fumipennis en los pollos $(n=45)$ fue del $56 \%$, la más alta reportada para cualquier ave rapaz. La prevalencia e intensidad de infestación fue similar para machos y hembras, debido posiblemente a que los números de cada sexo en esta población fueron similares. Encontramos que estos ectoparásitos presentaron una distribución espacial dispersa, de modo que la proximidad de cualquier nido a cualquier otro dentro de la colonia no influyó en la prevalencia ni en la carga parasitaria. La productividad de los nidos con jóvenes parasitados $(1.3 \pm 0.5$ joven/nido) fue similar a la de los nidos con jóvenes no parasitados $(1.4 \pm 0.6$ joven/nido; $P>0.05)$. En términos de ubicación espacial, la productividad general (número de jóvenes por nido exitoso) de la colonia estuvo afectada por la prevalencia de Olfersia fumipennis. La condición de colonialidad (i.e., alta densidad de

\footnotetext{
${ }^{1}$ Email address: estrella@ cibnor.mx

${ }^{2}$ Present address: Universidad Autónoma de Sinaloa, Facultad de Ciencias del Mar, Mazatlán, Sinaloa 82000 México.
} 
nidos) probablemente causó una elevada prevalencia general de infección. Uno de los costes de nidificar en condiciones coloniales podría ser tener una alta prevalencia de parásitos. Estudios adicionales sobre la prevalencia de Olfersia fumipennis y el estado sanitario y condición corporal de los pollos son necesarios para evaluar la salud de las poblaciones de P. haliaetus.

[Traducción de los autores editada]

Louse flies (Olfersia fumipennis) are obligate bloodsucking ectoparasites in the Hippoboscidae family that infest a wide range of avian hosts (Bequaert 1955, Maa 1969). Louse flies can adversely affect body condition in some species (Senar et al. 1994, Bize et al. 2004), but in others no effect has been detected (Tella et al. 1995, Lesko and Smallwood 2012). Louse flies have a high specificity for avian hosts and their prevalence varies between host taxa and sites (Tella et al. 1998). One key factor influencing parasitism is whether the host breeds under colonial or solitary conditions (Tella et al. 1995, Hoi et al. 1998). One of the costs of breeding in high densities (e.g., under colonial conditions) is that parasite transmission is facilitated and host birds experience a higher prevalence of parasites (Tella 2002). Although the occurrence and host specificity of louse flies have been widely documented, little is known about their prevalence under colonial conditions, particularly in host nestlings (Senar et al. 1994, Tella et al. 1995, Tompkins et al. 1996, Saino et al. 1998). Ospreys (Pandion haliaetus) reach the highest breeding densities in the world in some parts of the Baja California peninsula, Mexico (Rodríguez-Estrella et al. 2006). In some coastal lagoons such as San Ignacio and Ojo de Liebre, Baja California Sur (BCS), Ospreys nest in colonial conditions. We estimated the prevalence and infestation of louse flies on nestlings of an Osprey colony, and evaluated whether these values were influenced by nestling sex. We also evaluated whether louse fly prevalence affected the overall reproductive success of this Osprey colony. Lastly, we determined whether prevalence of louse flies was influenced by the spatial arrangement of occupied nests within the colony, with the hypothesis that louse fly prevalence and infestation intensity should be similar when neighboring nests were parasitized.

\section{METHODS}

We studied Ospreys at a breeding colony in the San Ignacio Lagoon, BCS. Ospreys tend to breed most densely near shallow waters (Bierregaard et al. 2016) and this lagoon provided such conditions. The climate was warm and dry, with mean annual temperature ranging between $18-22^{\circ} \mathrm{C}$. Rain occurred mainly during the summer and was influenced by the hurricane season; mean annual precipitation was $<150 \mathrm{~mm}$. Vegetation was dominated by plant species common in the adjacent mainland shrubland (Shreve 1959). Ospreys constructed nests on two small isles (total area $=1.3$ $\mathrm{km}^{2}$ ), Isla Garzas and Isla Pelícanos (Fig. 1). Although Osprey densities of almost 100 breeding pairs $/ \mathrm{km}^{2}$ have been estimated here annually, abundance of breeding pairs has varied greatly over the last $10 \mathrm{yr}$, with a low of 60 pairs $/ \mathrm{km}^{2}$ in 2001 (Reitherman and Storrer 1981, Danemann 1994, Rodríguez-Estrella et al. 2006 and unpubl. data; Fig. 1). Based on the estimated density on these islands, this breeding colony was one of the densest in the world (Poole 1989). However, during the last decade, breeding density has declined precipitously in this colony ( $R$. Rodríguez-Estrella unpubl. data).

The Isla Garzas and Isla Pelícanos Osprey breeding colony was monitored for $10 \mathrm{yr}$ to evaluate reproductive rate (Rodríguez-Estrella et al. 2006). For this study, we sampled the Osprey colony during the 2001 breeding season and looked for ectoparasites while banding nestlings in April-June. Nestling age was estimated according to plumage characteristics and body measurements (e.g., wing chord; following Danemann 1994), and averaged $45 \mathrm{~d}$ (range $=32-59 \mathrm{~d}$ ) at sampling. We sampled only nestlings because of the logistics of working on the islands, and to minimize effects of age on parasite prevalence.

We visually examined nestlings at the start of handling to look for louse flies following a standard protocol (Tella et al. 1998, 2000). This protocol ensured that all flies on each bird were detected and counted. We manually captured louse fly specimens during the first 2 min of handling and preserved them in $70 \%$ ethanol for identification in the laboratory. Louse flies parasitizing nestling Ospreys at the San Ignacio Lagoon were identified as Olfersia fumipennis Sahlberg, 1886. We used an arbitrary rank scale to classify the level of louse fly infestation (i.e., load) on each nestling, as follows: $0=$ no flies, $1=1-$ 4 flies, $2=5-9$ flies, $3=>9$ flies. Although the 


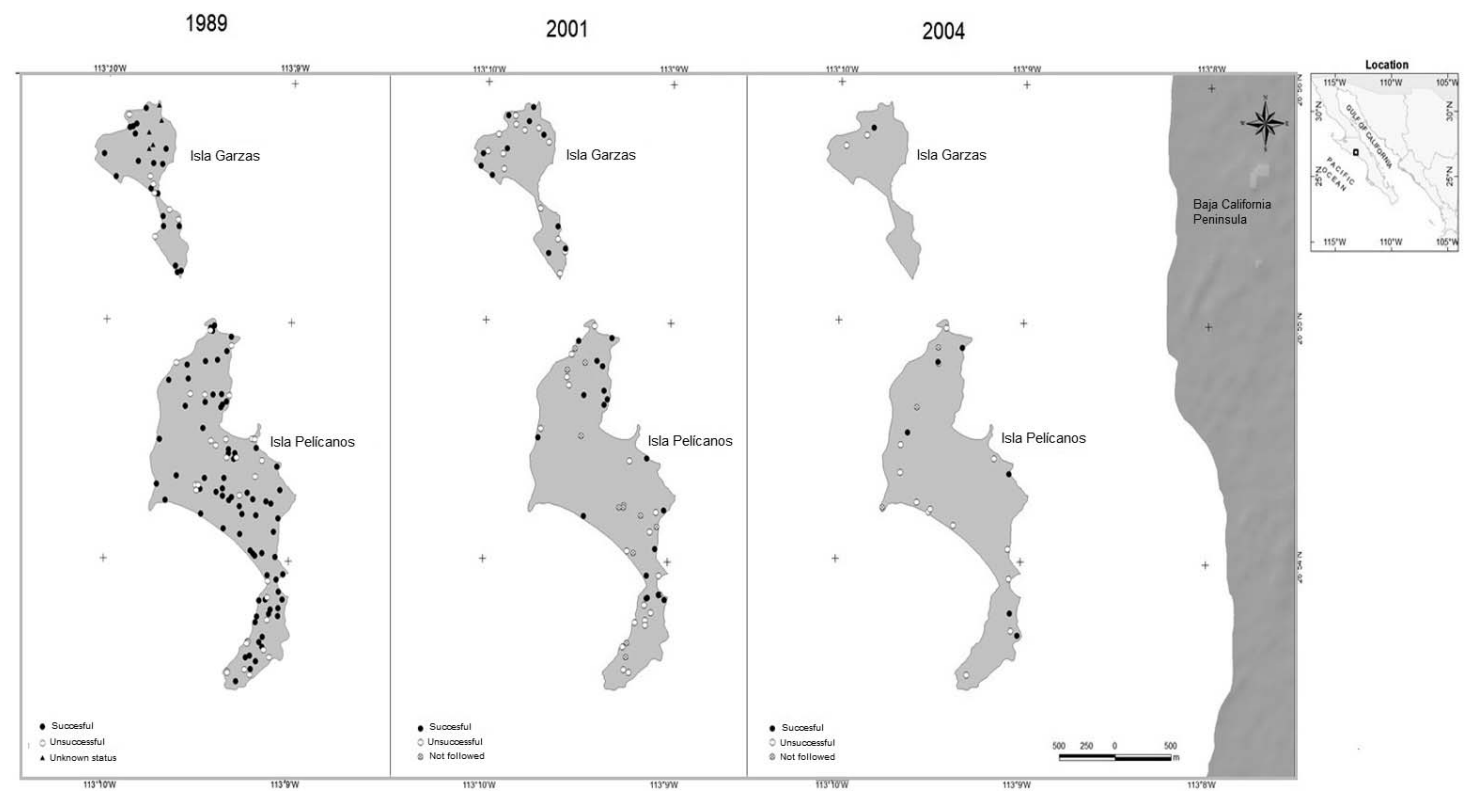

Figure 1. Location of Osprey nests at San Ignacio Lagoon islands during 1989, 2001, and 2004. The proportion of nests that were successful was significantly higher in 1989 (65\%) than in 2001 (41\%). In 2001 we did not monitor Osprey nests ( $n$ $=8$ ) near other nesting bird species (e.g., herons) for which our presence could disturb their nesting behavior. Note the low number of nests in 2004. Data from 1989 were adapted from Daneman 1994.

number of flies on a nestling may vary over time due to their mobility, we expected that the same pattern of fly displacement would have similarly affected all the nestlings sampled. We collected one drop of blood from each nestling for sex determination by molecular procedures at the Molecular Ecology Laboratory of Estación Biológica de Doñana (Ellegren 1996, Fridolfsson and Ellegren 1999).

We examined correlations between the number of louse flies and the nestling sex by means of the Spearman rank correlation test. A paired-sample $t$ test was used to compare productivity between nests containing parasitized young and those with no parasitized young (Statistica v. 6). A $P<0.05$ significance level was used for all tests. We report values as mean $\pm \mathrm{SD}$.

We defined reproductive terms following Steenhof and Newton (2007). Occupied nests were those with signs of reproduction (e.g., copulation or courtship behaviors, refurbished nest, nest repaired and fresh sticks, two adults observed on or near the nest). A used nest was one at which (1) eggs were laid, (2) an adult was observed in an incubation position, or (3) young were raised. A nesting attempt occurred when eggs were laid. A successful nest was one at which at least one nestling survived until fledging. Nesting success was defined as the proportion of occupied nests where young were raised to the age of fledging. Pairs were considered to be successful when fledglings or well-grown young were observed around the nest or in the nest prior to fledging. Productivity referred to the number of young that reached the minimum acceptable age for evaluating success, and was calculated as the average number of fledglings per nest. We estimated the productivity on the basis of successful nests (a metric we termed "overall productivity") and also on the basis of nesting attempts.

We visited the nests on both islands throughout the breeding season. We averaged seven visits during the nesting period, but the frequency of visits to the colony depended upon the estimated age of young, as we needed to count the exact number of fledglings. We counted all occupied nests during the first and second visits to the islands, because of the nesting asynchrony in this Osprey population. During each visit, we marked all new nests and recorded their contents (i.e., number of eggs, young, or fledglings); we recorded nests as successful or unsuccessful and noted any dead young. The age we considered young successfully fledged averaged 
approximately $57 \mathrm{~d}$ (Danemann 1994). We then estimated the productivity of nests.

We performed a spatial correlation analysis to determine whether the proximity of nests to each other within the colony influenced the prevalence and intensity of louse fly infestation. This analysis helps us understand the degree to which one observation (e.g., a parasitized nest) is similar to other nearby observations (e.g., nest). In summary, a correlation was performed between one variable at a location (e.g., young parasitized, successful nest), and another variable in Ospreys or nests (e.g., louse load, prevalence) at the neighboring locations. We used this analysis to determine whether closer nests had more flies than more isolated nests in the colony or if the louse fly prevalence distribution was more dispersed. We also used this test to determine whether fly load distribution was correlated with nesting success and number of fledglings/nest. We wanted to know if nesting success was spatially affected by fly prevalence in nests, and if the number of fledglings/nest spatially influenced the louse fly prevalence. Finally, we wanted to determine if overall productivity in the colony was spatially affected by louse fly prevalence. We used the Moran's I statistic to measure spatial autocorrelation (Anselin et al. 2006). We first obtained the basic diagnostics for spatial autocorrelation, heteroscedasticity and non-normality implemented for the standard ordinary least-squares regression. The method employed sparse spatial weights that were constrained to weights that were intrinsically symmetric. We used the K-Nearest Neighbor with order 4 (GeoDa v 0.9). Spatial autocorrelation indicates if there is clustering or dispersion in a map: a positive Moran's $I$ suggests that data were clustered and a negative Moran's I implies data were dispersed. The absence of autocorrelation indicates data were independent.

\section{RESULTS}

We analyzed samples from 45 nestlings (20 males, 22 females, 3 unsexed; $73 \%$ of the nestlings in colony) from 34 different nests. We found louse flies in $65 \%$ of the nests sampled $(n=34)$. Louse fly prevalence in nestlings $(n=45)$ was $56 \%$. Louse fly load averaged $4.7 \pm 3.4$ flies/nestling. The ratio of female to male nestlings in the colony as a whole was near parity (1.0:0.9, F:M), as was the ratio among nests with more than one nestling (0.8:1.0, F:M). Louse fly load was not significantly correlated with the nestlings' sex $(r=0.19 ; P>0.05$; Fig. 2$)$. The a.

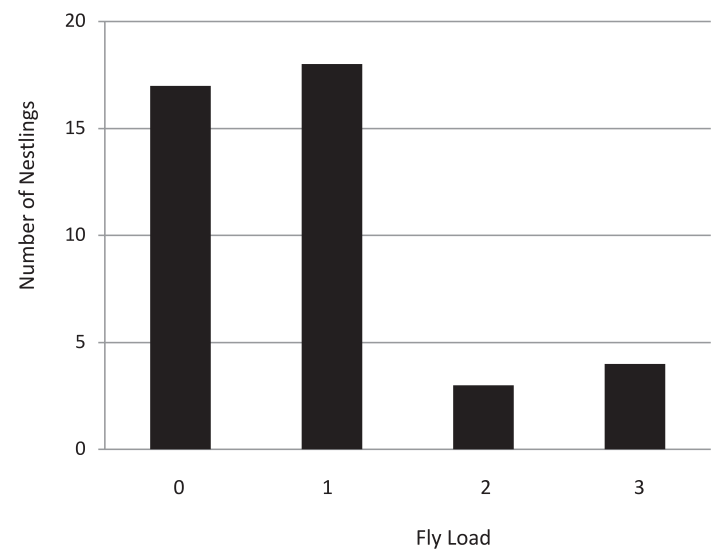

b.

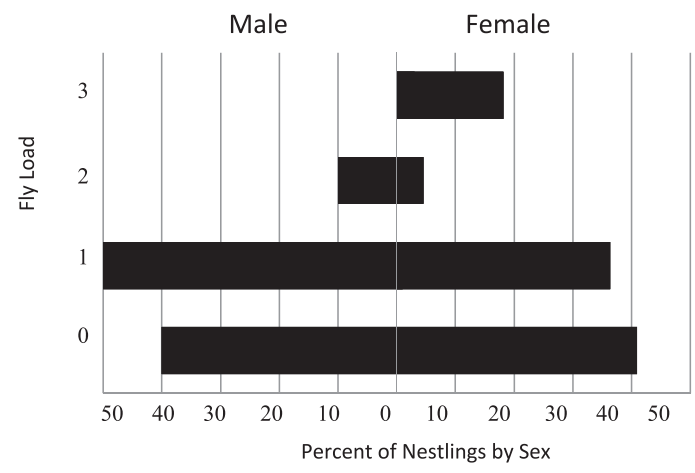

Figure 2. Louse fly infestation on Osprey nestlings at San Ignacio Lagoon, Baja California Sur during the 2001 breeding season: (a) Level of infestation (number of flies/nestling), and (b) fly infestation by sex. Number of flies indicates the louse fly load categories.

overall productivity recorded in the San Ignacio colony was $1.3 \pm 0.5$ young/successful nest. Productivity in nests containing at least one parasitized nestling (1.3 \pm 0.5 young/nest, [26 young in 20 nests]) did not differ significantly from that in nests with no parasitized young $(1.4 \pm 0.6$ [19 young in 14 nests $(t=-0.30 ; d f=32 ; P>0.05)$.

The autocorrelation spatial analysis showed that the proximity of any Osprey nest to other nests within the colony did not influence the prevalence of louse flies nor the louse fly load (Moran's $I=0.18, P=0.15$ ). The success of a nest did not seem to be spatially affected by fly prevalence in nests (Moran's $I=0.82, P=0.22$ ). 


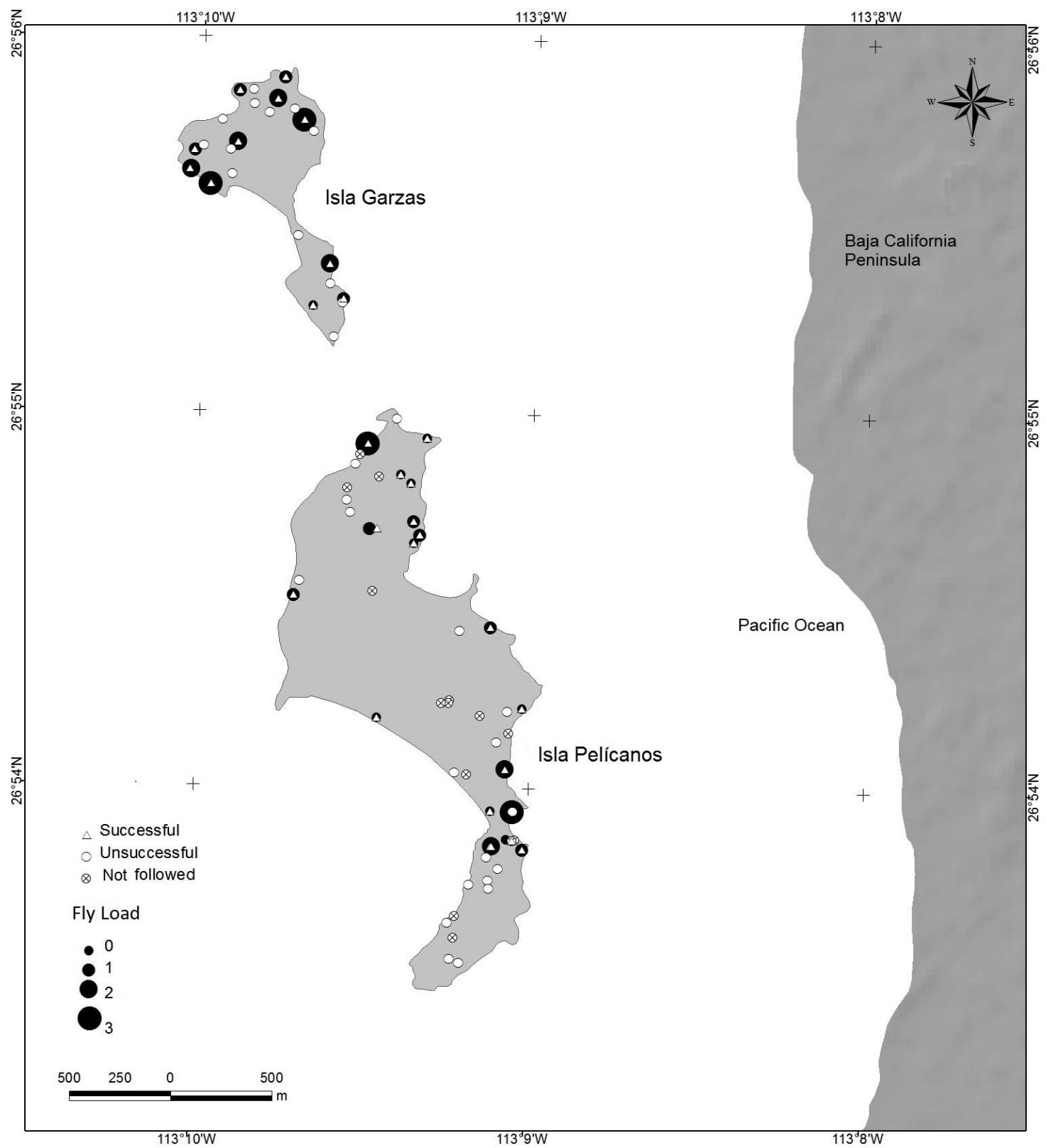

Figure 3. Prevalence of louse flies and intensity of infestation (fly load) on Osprey nestlings at San Ignacio Lagoon, Baja California Sur during the 2001 breeding season. Louse fly load categories, represented by circles of different size, are described in Methods.

Also, the number of fledglings/nest did not spatially influence the louse fly prevalence (Moran's $I=0.05, P=0.25)$. However, in terms of spatial location, the overall number of young per successful nest in this colony was affected by louse fly prevalence (Moran's $I=-0.042, Z=-5.52 ; P<$ $0.0001)$. This means that the spatial distribution of louse fly prevalence was dispersed and may affect productivity of any nest within the colony similarly (Fig. 3). 
We found other ectoparasites on some of the nestlings sampled. Two nestlings had three louse flies each with $>10$ Mallophaga lice, and another nestling had two ticks and six Mallophaga lice.

\section{DISCUSSION}

The louse fly Olfersia fumipennis shows a high specificity for parasitizing Ospreys (Bequaert 1955, Maa 1969). To our knowledge, this is the first report on the prevalence of a bloodsucking fly in colonial conditions. We found a high prevalence of louse flies in both nests and nestlings. The $56 \%$ prevalence rate of louse flies is the highest reported to date for Ospreys and for nestlings of any raptor species. For Ospreys in Ontario, louse flies were not recorded either for nestlings or for adults (Miller et al. 1997). Prevalence of louse flies was $39 \%$ in Little Owl (Athene noctua) adult and young (Tomé et al. 2005), $14 \%$ in Red-tailed Hawk (Buteo jamaicensis) nestlings (Smith et al. 1998), and 4\% in American Kestrel (Falco sparverius) adults (Liébana et al. 2011). These prevalence values are for raptors that nest in low densities and solitary conditions. Even for Burrowing Owls (Athene cunicularia) that nested in clusters in Idaho, the prevalence of flies was low: only "two specimens of a fly (Family: Carnidae) from one brood ( $n=6$ juveniles) of owls" were recorded in a sample of 11 nestlings from four broods (prevalence 18\%; Smith 1999). The high prevalence of louse flies in San Ignacio Lagoon Ospreys might be due to the colonial nesting conditions, as colonialism can facilitate a higher prevalence and infestation (Tella 2002). Our results of the autocorrelation spatial analysis showed that parasitized nests and the intensity of parasitism were not correlated with the condition (parasitized or not) of nearby nests. Louse flies can fly and move between nests, whether the nests are close neighbors or not, and because the data were not independent, it is likely that colonial conditions (i.e., high nest density) caused increased louse fly prevalence overall. We did not capture Osprey adults, so we do not know the role of adults in louse fly movement within the colony.

Louse flies spend most of their adult lives on the host but can move between individuals (Waage 1979), and can negatively affect the birds' body condition (Senar et al. 1994, Owen et al. 2010), productivity (Tompkins et al. 1996), growth rate, and mortality, sometimes with sex-specific differences (Bize et al. 2005). In our study, we found no differences between sexes; male and female nestlings showed similar levels of fly prevalence and infestation. This may be because the ratio of the sexes in this population was near parity both in the whole colony and in the nests where more than one nestling was present. Additionally, because of the dispersed distribution of louse flies within the colony, any nestling had a similar probability of being parasitized, at least from a spatial perspective.

Osprey nests containing parasitized young had a similar productivity as those with young that were not parasitized. It is well established that parasites can influence breeding success in birds (Loye and Zuk 1991). For example, infestations of bloodsucking blackflies (Simulium canonicolum) caused nestling mortality of Red-tailed Hawks (up to $12 \%)$, mostly due to the cumulative effects of infestations, including physical harassment, Leucocytozoon (a blood protozoan transmitted by blackflies) infection, and direct loss of blood from biting flies (Smith et al. 1998). However, louse fly infestation did not seem to affect the breeding performance of colonial Ospreys on the Baja California peninsula. Detailed studies should be made on the health and body condition of Ospreys in Baja California colonies because new recruits to this population were decreasing in numbers in recent years and it is important to determine any role ectoparasites may play in this trend. It is known that louse flies can have a debilitating effect either by themselves or by transmitting endoparasites (McClure 1984, Loye and Zuk, 1991, Bize et al. 2004, Owen et al. 2010). Endoparasites can affect body condition and individual quality, cause delayed reproduction, and can transmit viruses (Gancz et al. 2004, Tomé et al. 2005, Liébana et al. 2011), thus increasing host bird mortality. Endoparasites can even reduce future reproductive success (Bennett et al. 1993, Tella et al. 1999, Bize et al. 2004) by diminishing their host fitness. Only the haemospororin parasite (Haemoproteus spp.) has been reported for Ospreys (Bierregaard et al. 2016), but we lack information on endoparasites of San Ignacio Lagoon Ospreys.

It is likely that the Osprey populations on the Baja California peninsula have adapted to the parasitism dynamics under these colonial conditions and, even after many years of enduring high parasite prevalence, the population may remain stable over the long term. In fact, the productivity rates (fledglings/ successful nest) in 1989 (1.5 young per nest; Danemann 1994), 1998 (1.7 \pm 0.5$)$ and 2000 (1.5 $\pm 0.6)$ were similar to that found in 2001 (1.3 \pm 0.5; Table 1). Nesting success was higher in 1989 (47\%; Danemann 1994) compared to 1998 (35\%), 
Table 1. Osprey productivity at the San Ignacio Lagoon, Baja California Sur, Mexico, during the 2001 breeding season. Nests containing at least one young parasitized with louse flies were considered as nests with louse flies. Productivity was defined as fledglings/successful nest (mean $\pm \mathrm{SD})$. Other reproductive parameters defined in text.

\begin{tabular}{lc}
\hline \multicolumn{1}{c}{ ReProductive PARAmeter } & MEAsurement \\
\hline No. of occupied nests & 76 \\
No. of successful nests (\%) & $31(40.7)$ \\
No. of eggs & 180 \\
No. of eggs that hatched & 122 \\
No. fledglings (\% fledging success) & $41(34)$ \\
No. nestlings sampled/total nestlings & $45 / 62(72.5)$ \\
$\quad$ ca. 45 d old) (\% sampled) & 26 \\
No. of young with louse flies & 19 \\
No. of young without louse flies & $1.36 \pm 0.6$ \\
Productivity at nests without louse flies & $1.30 \pm 0.5$ \\
Productivity at nests with louse flies & $1.32 \pm 0.5$ \\
Overall productivity (young/successful nest) & $0.7 \pm 0.7$ \\
Fledglings/nesting attempt & \\
\hline
\end{tabular}

$2000(31 \%)$ and 2001 (41\%; Rodríguez-Estrella et al. 2006). Unfortunately, we do not have data on louse fly prevalence for 1998 and 2000; thus, we cannot draw any conclusions about the population trends relative to parasite prevalence. However, a high prevalence of parasitism might be part of the cost of nesting in colonial conditions. Among the apparent benefits for nesting in colonial conditions for Ospreys on the islands of San Ignacio Lagoon are the high prey availability (Danemann and de la CruzAgüero 1993), the lack of terrestrial predators, and the apparent ease in finding mates for reproduction.

Further research is needed to determine whether parasite prevalence in colonial Ospreys is naturally high and differs from that of Ospreys that nest solitarily, or whether prevalence varies between years in response to external factors such as climate conditions and/or food availability. Research is needed on the endoparasites' prevalence and transmission in this Osprey colony. Such information might help explain the effects of parasitism and disease on the demography and decline of populations (Hatcher et al. 2006) or metapopulations. Henny et al. (2008) found that the Osprey colony of San Ignacio Lagoon was declining but they did not identify any cause of this decline. Our results highlight the need for further studies on the effects of louse fly parasitism on Osprey health, particularly under colonial conditions.

\section{ACKNOWLEDGMENTS}

We thank A. Cota, M. Lobato, and B. Granados for field assistance. J. M. Godoy, at the Laboratory of Molecular Ecology, Estación Biológica de Doñana, Spain, determined the sex of nestling Ospreys. M. G. López Campos, at the Laboratory of Acarology, UNAM, identified the Hippoboscid louse fly. One specimen was deposited at the Entomological Collection of the Centro de Investigaciones Biológicas del Noroeste (La Paz, Baja California Sur, Mexico; accession number CACIB 0326). This study was partially supported by CIBNOR and the Consejo Nacional de Ciencia y Tecnología through grants SEMARNATCONACyT C01-0318 and 0023861, and SEP-CONACyT 45737 and 155956 to RRE. LBRR received support from the Universidad Autónoma de Sinaloa for writing this report. RRE received a CONACyT sabbatical grant at the University of Arizona during the writing of this report. Two anonymous referees made useful comments that greatly improved an earlier draft. Sampling was conducted under permit FAUT-0055 from SEMARNAT, México.

\section{Literature Cited}

Anselin, L., I. Syabri, and Y. Kho (2006). GeoDa: Introduction to spatial data analysis. Geographical Analysis 38:522.

Bennett, G. F., M. A. Peirce, and R. W. Ashford (1993). Avian Haematozoa: mortality and pathogenicity. Journal of Natural History 27:993-1001.

Bequaert, J. C. (1955). The Hippoboscidae or louseflies (Diptera) of mammals and birds, Part II: Taxonomy, evolution and revision of American genera and species. Entomologica Americana 34/35/36:1-611.

Bierregaard, R. O., A. F. Poole, M. S. Martell, P. Pyle, and M. A. Patten (2016). Osprey (Pandion haliaetus). In The Birds of North America (P. G. Rodewald, Editor). Cornell Lab of Ornithology, Ithaca, New York, USA. https://birdsna.org/Species-Account/bna/species/ osprey.

Bize, P., A. Roulin, J. L. Tella, L. Bersier, and H. Richner (2004). Additive effects of ectoparasites over reproductive attempts in the long-lived Alpine Swift. Journal of Animal Ecology 73:1080-1088.

Bize, P., A. Roulin, J. L. Tella, and H. Richner (2005). Female-biased mortality in experimentally parasitized Alpine Swift Apus melba nestlings. Functional Ecology 19:405-413.

Danemann, G. D. (1994). Biología reproductiva del águila pescadora (Pandion haliaetus) en Isla Ballena, Laguna San Ignacio, Baja California Sur, México. M. S. thesis. Centro Interdisciplinario de Ciencias del Mar, Instituto Politécnico Nacional, La Paz, Baja California Sur, México.

Danemann, G. D., and J. de la Cruz-Agüero (1993). Ichthyofauna of San Ignacio Lagoon, Baja California Sur, Mexico. Ciencias Marinas 19:333-341.

Ellegren, H. (1996). First gene in the avian W chromosome (CHD) provides a tag for universal sexing of non-ratite birds. Proceedings of the Royal Society of London B 263:1635-1641 
Fridolfsson, A. K., and H. Ellegren (1999). A simple and universal method for molecular sexing of non-ratite birds. Journal of Avian Biology 30:116-121.

Gancz, A. Y., I. K. Barker, R. Lindsay, A. Dibernardo, K. Mckeever, and B. Hunter (2004). West Nile virus outbreaks in North American owls, Ontario. Emerging Infectious Diseases 10:2135-2142.

Hatcher, M. J., J. T. A. Dick, and A. M. Dunn (2006). How parasites affect interactions between competitors and predators. Ecology Letters 9:1253-1271.

Henny, C., D. W. Anderson, A. Castellanos, and J.-L. E. Cartron (2008). Region-wide trends of nesting Ospreys in northwestern Mexico: a three-decade perspective. Journal of Raptor Research 42:229-242.

Hoi, H., A. Darolova, C. König, and J. Kristofík (1998). The relation between colony size, breeding density and ectoparasite loads of adult European Bee-eaters (Merops apiaster). Écoscience 5:156-163.

Lesko, M. J., and J. A. Smallwood (2012). Ectoparasites of American Kestrels in northwestern New Jersey and their relationship to nestling growth and survival. Journal of Raptor Research 46:304-313.

Liébana, M. S., M. Á., Santillán, A. C. Cicchino, J. H. Sarasola, P. Martínez, S. Cabezas, and M. S. Bó (2011). Ectoparasites in free-ranging American Kestrels in Argentina: implications for the transmission of viral diseases. Journal of Raptor Research 45:335-341.

Loye, J. E., and M. Zuk (1991). Bird-Parasite Interactions: Ecology, Evolution and Behavior. Oxford University Press, Oxford, UK.

Maa, T. C. (1969). Notes on the Hippoboscidae (Diptera). Pacific Insects. Monograph 6, Entomology Department, Bernice P. Bishop Museum, Honolulu, HI, USA.

McClure, E. (1984). The occurrence of hippoboscid flies on some species of birds in southern California. Journal of Field Ornithology 55:230-240.

Miller, M. J. R, P. J. Ewins, and T. D. Galloway (1997). Records of ectoparasites collected on Ospreys from Ontario. Journal of Wildlife Diseases 33:373-376.

Owen, J. P., A. C. Nelson, and D. H. Clayton (2010). Ecological immunology of bird-ectoparasite systems. Trends in Parasitology 26:530-539.

Poole, A. (1989). Ospreys: A Natural and Unnatural History. Cambridge University Press, Cambridge, UK.

Reitherman, B., and J. Storrer (1981). A Preliminary Report on the Reproductive Biology and Ecology of the Whale Island Osprey (Pandion haliaetus) Population, San Ignacio Lagoon, Baja California Sur, México. Western Foundation Vertebrate Zoology, Los Angeles, CA, USA.

Rodríguez-Estrella, R., L. B. Rivera-Rodríguez, and E. Morales (2006). Breeding biology and success of the Osprey (Pandion haliaetus) in Laguna San Ignacio, B.C.S., México, in 1998, 2000 and 2001. In Current Raptor Studies in Mexico (R. Rodríguez-Estrella, Editor). Centro de Investigaciones Biológicas del Noroeste and CONABIO, México, D.F., México. pp. 149-162.

Saino, N., S. Calza, and A. P. Møller (1998). Effects of a dipteran ectoparasite on immune response and growth trade-offs in Barn Swallow, Hirundo rustica, nestlings. Oikos 81:217-228.

Senar, J. C., J. L. Copete, J. Domenech, and G. Von Walter (1994). Prevalence of louse-flies (Diptera, Hippoboscidae) parasiting a cardueline finch and its effect on body condition. Ardea 82:157-160.

Shreve, F. (1959). Vegetation of the Sonoran Desert. In Vegetation and Flora of the Sonoran Desert. Vol. I (F. Shreve and I. L. Wiggins, Editors). Stanford University Press, Stanford, CA, USA.

Smith, B. W. (1999). Nest-site selection, ectoparasites, and mitigation techniques: studies of Burrowing Owls and artificial burrow systems in southwestern Idaho. M.S. thesis, Boise State University, ID, USA.

Smith, R. N., S. L. Cain, S. H. Anderson, J. R. Dunk, and E. S. Williams (1998). Blackfly-induced mortality of nestling Red-tailed Hawks. The Auk 115:368-375.

Steenhof, K., and I. Newton (2007). Assessing nesting success and productivity. In Raptor Research and Management Techniques Manual (D. M. Bird and K. L. Bildstein, Editors). Hancock House, Surrey, British Columbia, Canada. pp. 181-192.

Tella, J. L. (2002). The evolutionary transition to coloniality promotes higher blood parasitism in birds. Journal of Evolutionary Biology 15:32-41.

Tella, J. L., G. Blanco, M. G. Forero, A. Gajon, J. A. Donazar, and F. Hiraldo (1999). Habitat, world geographic range, and embryonic development of hosts explain the prevalence of avian hematozoa at small spatial and phylogenetic scales. Proceedings of the National Academy of Sciences of the United States of America 96:17851789.

Tella, J. L., A. Gajón, C. Gortázar, and J. J. Osacar (1998). High host specificity of Crataerina melbae (Diptera: Hippoboscidae) in a mixed colony of birds. Journal of Parasitology 84:1980-1200.

Tella, J. L., C. Gortázar, A. Gajón, and J. J. Osacar (1995). Apparent lack of effects of a high louse-fly infestation (Diptera, Hippoboscidae) on adult colonial Alpine Swifts. Ardea 83:435-439.

Tella, J. L., R. Rodríguez-Estrella, and G. Blanco (2000). Louse flies on birds of Baja California. Journal of Wildlife Diseases 36:154-156.

Tomé, R., N. Santos, P. Cardia, N. Ferrand, and E. Korpimäki (2005). Factors affecting the prevalence of blood parasites of Little Owls Athene noctua in southern Portugal. Ornis Fennica 82:63-72.

Tompkins, D. M., T. Jones, and D. H. Clayton (1996). Effect of vertically transmitted ectoparasites on the reproductive success of Swifts (Apus apus). Functional Ecology 10:733-740.

Waage, J. K. (1979). The evolution of insect/vertebrate associations. Biological Journal of the Linnean Society $12: 187-224$

Received 20 July 2017; accepted 7 September 2018 Associate Editor: Stephen B. Lewis 